\title{
Effect of spacing, fertilizers and varieties on growth and yield parameters of okra (Abelmoschus esculantus (L.) Moench)
}

\author{
Vikash Kumar $^{1 *}$, S.K. Dhankhar ${ }^{1}$, Chandanshive Aniket Vilas', Rajesh Kathwal ${ }^{2}$ and \\ Neha Yadav ${ }^{1}$ \\ ${ }^{1}$ Department of Vegetable Science, Choudhary Charan Singh Haryana Agricultural University, Hisar-125004 \\ (Haryana), INDIA \\ ${ }^{2}$ Department of Agronomy, Choudhary Charan Singh Haryana Agricultural University, Hisar-125004 (Haryana), \\ INDIA \\ *Corresponding author. E-mail: vikaskamboj7005@gmail.com
}

Received: September 26, 2015; Revised received: May 19, 2016; Accepted: July 27, 2016

\begin{abstract}
The experiment was conducted during spring summer seasons of 2013 and 2014 conducted at Research Farm of Vegetable Science, CCS HAU, in summer season. There were three spacing, three fertilizer levels and two varieties in split-split plot design with three replications. Growth parameters of okra crop were significantly affected by spacing, fertilizer and varieties. Highest plants were observed in wider spacing with fertilizer application of 187.5 $\mathrm{kg} \mathrm{N}+75 \mathrm{~kg} \mathrm{P}_{2} \mathrm{O}_{5}+60 \mathrm{~kg} \mathrm{~K} 2 \mathrm{O}$ per hectare in variety HBT-49-1. However, numbers of branches were highest in variety Hisar Unnat. Yield attributes like first fruiting node, intermodal length, fruit length and diameter etc. were highest in variety HBT-49-1 resulting in highest fruit yield (q/ha) in spacing $30 \mathrm{~cm} \times 10 \mathrm{~cm}$ with the application of $187.5 \mathrm{~kg} \mathrm{~N}$ $+75 \mathrm{~kg} \mathrm{P} \mathrm{O}_{5}+60 \mathrm{~kg} \mathrm{~K} \mathrm{O}_{2}$ per hectare. The seed yield attributes and yield was significantly affected by spacing, fertilizer and varieties. Finally, spacing $30 \mathrm{~cm} \times 10 \mathrm{~cm}$ resulted in higher growth parameters, yield attributes and yield with the application of $187.5 \mathrm{~kg} \mathrm{~N}+75 \mathrm{~kg} \mathrm{P} \mathrm{O}_{5}+60 \mathrm{~K}_{2} \mathrm{O}$ in variety HBT-49-1 of okra.
\end{abstract}

Keywords: Fertilizer, Okra Spacing, Varieties, Yield

\section{INTRODUCTION}

Okra [Abelmoschus esculantus (L.) Moench] is one of the most important summer vegetable crop grown for its immature fruits, which are commonly used in culinary preparation. Its tender green fruits are also canned, dehydrated or frozen for off season consumption. The crop is grown in both spring-summer (February-May) and rainy seasons in tropical and subtropical regions of the country. In North India, springsummer crop remains free from the infections of yellow vein mosaic virus disease and fetches better price in the market. In India, the second largest producer of okra after China, it occupies an area of 4.98 lack hectares with average production and productivity of 57.48 lakh tonnes and $11.75 \mathrm{t} / \mathrm{ha}$, respectively, and is $3.9 \%$ of total vegetable production (Vanitha et al., 2013), while in Haryana, it occupies an area of 18,200 hectares with an average production and productivity of 1.45 lakh tonnes and 7.96 tonnes/ha, respectively (Anonymous, 2011).

The main okra growing areas of Haryana State are Sonipat, Karnal, Panipat and Hansi where the farmers grow okra on both sides of the ridges by dibbling 4 to 5 seed per hill at very close spacing using 50-60 kg seed compared to recommended rate of $20-25 \mathrm{~kg} / \mathrm{ha}$ and 3-4 times higher amount of nitrogen against rec- ommended dose of $100 \mathrm{~kg} / \mathrm{ha}$. Application of exceptionally high nitrogen dose in a number of split applications in the standing crop helps to extend the harvesting period and increase the fruit yield significantly. It has been recommended to grow spring-summer crop of okra at $30 \times 20 \mathrm{~cm}$ spacing with nitrogen $100 \mathrm{~kg}$ and phosphorus $50 \mathrm{~kg} / \mathrm{ha}$ in Haryana. Nath et al. (1987) have advocated $30 \times 15 \mathrm{~cm}$ and $30 \times 13 \mathrm{~cm}$ spacing, respectively for growing okra during summer season. A new promising advance line HBT-49-1 of okra found superior to check Hisar Unnat for yield in station trail of three years in spring-summer on recommended spacing and dose of fertilizers. It has been observed that each genotype has its own requirement of spacing and fertilizer for proper growth and development in a particular season since okra is a photosensitive crop.HBT-49-1 has different plant canopy (taller and stout) than earlier released varieties Hisar Unnat and Varsha Uphar. Hence, the present study has been planted to find out the effect of spacing and fertilizer on growth and yield of okra, A. esculantus.

\section{MATERIALS AND METHODS}

The present study was carried out at the Research Farm of the Department of Vegetable Science, CCS HAU, Hisar during spring-summer season, 2013 and 2014. Hisar is situated between $29^{\circ} 10^{\circ} \mathrm{N}$ latitude and ISSN : 0974-9411 (Print), 2231-5209 (Online) All Rights Reserved @ Applied and Natural Science Foundation www.jans.ansfoundation.org 
$15^{\circ} 46^{\circ} \mathrm{E}$ longitude at mean elevation of 215.2 meter above mean sea level, has a semi arid, sub-tropical climate, hot and dry winds during summer and dry severe cold in the winter are the common features of this region. The mean maximum and minimum temperature of $42^{0}$ to $46^{\circ} \mathrm{C}$ is quite common during summer months (May-June). The rainfall is restricted mainly to the monsoon months from July to September, but sometime pre-monsoon showers occur in June also. The soil of this area is derived from IndoGangentic alluvium, which is very deep and sandy loam in texture. The $\mathrm{pH}$ of the soil varies from 7.8 to 8.9 since these soil are poor in organic carbon, available nitrogen, medium in phosphorus and rich in potash content. The experimental material for the present investigation was comprised of two varieties, three spacing and three fertilizer levels. The experiment with two varieties (Hisar Unnat and HBT-49-1), three spacing $(30 \times 5 \mathrm{~cm}, 30 \times 10 \mathrm{~cm}$ and $30 \times 15 \mathrm{~cm})$ and three fertilizers levels $\left(150 \mathrm{~kg} \mathrm{~N}+60 \mathrm{~kg} \mathrm{P}_{2} \mathrm{O}_{5}, 187.5 \mathrm{~kg} \mathrm{~N}+\right.$ $75 \mathrm{~kg} \mathrm{P}_{2} \mathrm{O}_{5}+60 \mathrm{~kg} \mathrm{~K} 2 \mathrm{O}$ and $225 \mathrm{~kg} \mathrm{~N}+90 \mathrm{~kg} \mathrm{P}_{2} \mathrm{O}_{5}+$ $60 \mathrm{~kg} \mathrm{~K} \mathrm{~K}_{2} \mathrm{O}$ ) in okra was laid out in split-split block design with three replications. In each replication, there were 18 plots and each plot was of $3.6 \mathrm{~m} \times 3 \mathrm{~m}$ size accommodating three rows. 2-3 seeds per hill were sown and later thinned to one plant per hill. Recommended package of practices for other operations were followed to raise a healthy crop. Composite soil sample were taken from four different place of experimental field from a depth of $0-15 \mathrm{~cm}$ during season. The samples were analyzed to determine mechanical and chemical and composition of the soil. The soil was sandy loam with sand (55\%), silt (34\%) and clay (11\%). The chemical properties like electrical conductivity was $0.30\left(\mathrm{dS} / \mathrm{m}\right.$ at $\left.25^{\circ} \mathrm{C}\right), \mathrm{pH}(1: 2.5$ : water $) 8$ (alkaline), and organic carbon $(0.6 \%)$. The available nitrogen was $320 \mathrm{~kg} / \mathrm{ha}$ (low), phosphorus (17kg/ha) (medium) and potassium was $307 \mathrm{~kg} / \mathrm{ha}$ (rich).

\section{RESULTS AND DISCUSSION}

\section{Growth studies in okra}

Effect of spacing: Spacing $30 \times 15 \mathrm{~cm}$ and $30 \times 10 \mathrm{~cm}$ significantly produced taller plants at 45, 60 and 75 days after sowing and at harvest as compared to spacing $30 \times 15 \mathrm{~cm}$, but on par with each other. Spacing $30 \times 15 \mathrm{~cm}$ significantly resulted into higher number of branches (2.31) in okra as compared to 2.20 and 1.84 in $30 \times 10$ and $30 \times 5 \mathrm{~cm}$ spacing, respectively (Table 1). It might be due to more competition for light, space between the crop plants and okra height when grown at closer intra- row spacing of $30 \mathrm{~cm}$ than when grown at a wider intra-row spacing of $40 \mathrm{~cm}$. Hossain et al., (2001) also reported greater plant height from closer intra-row spacing than from wider intrarow spacing. Similar results were obtained by Gorachand et al., (1990) and Randhawa and Pannum (2000). As per the observation made by Ekwu and
Nwokwu (2012), plant height increased as the plant spacing increased from $50 \mathrm{~cm} \times 25 \mathrm{~cm}$ to $50 \mathrm{~cm} \times 50$ $\mathrm{cm}$ beyond which there was decrease in plant height, confirmed the results. The maximum number of branches (2.31) was obtained with $30 \mathrm{~cm}$ row to row spacing at $15 \mathrm{~cm}$. The reduced competition for light and other resources as well as reduced overlapping from adjacent okra plants within the population could have enabled the plants to utilize its energy for maximum branching. This result was similar to the findings of Saha et al., (2005), Ijoyah et al. (2010) and Maurya (2013) who reported a greater branch number at wider intra- row spacing of $40 \mathrm{~cm}$ compared to that produced from a reduced intra-row spacing of $20 \mathrm{~cm}$. Moreover, the vegetative growth characteristics results obtained may be attributed to the varying levels of intra-specific competition caused by the three plant spacing utilized in the experiment. In nature the competition effect may be completely absent until population density reaches some threshold at which resources become limited (Talukder $e t$ al., 2003 and Makinde and Macarthy; 2006).

Effect of fertilizer levels: Plant height of okra at different time intervals i.e. $37.16 \mathrm{~cm}$ at $45,69.55 \mathrm{~cm}$ at $60,110.35 \mathrm{~cm}$ at 75 days after sowing and $134.41 \mathrm{~cm}$ at final harvest was found maximum with fertilizer application of $187.5 \mathrm{~kg} \mathrm{~N}+75 \mathrm{~kg} \mathrm{P}_{2} \mathrm{O}_{5}+60 \mathrm{~kg} \mathrm{~K} 2 \mathrm{O}$ as compared to all other treatments. Plant height is a vegetative trait and height responds well to $\mathrm{N}$ availability. The basic function of nitrogen in plant is increased vegetative growth through cell elongation and cell enlargement. Nitrogen increased the growth photosynthetic activity of plant by stimulating its vegetative growth (Banger et al., 2000; Kushwaha, 1989; Chaurasia et al. 2001; Misra and Singh, 2005 and Kumar et al., 2013). Higher availability of nitrogen induced higher plant height in okra up to $25 \%$ higher recommended dose of $\mathrm{N}$ and $\mathrm{P}+50 \mathrm{~kg}$ potash but beyond this, the threshold limit may arise which failed to respond to $50 \%$ higher recommended dose of $\mathrm{N}$ and $\mathrm{P}+$ $50 \mathrm{~kg}$ potash $\left(\mathrm{F}_{3}: 225 \mathrm{~kg} \mathrm{~N}+90 \mathrm{~kg} \mathrm{P}_{2} \mathrm{O}_{5}+60 \mathrm{~kg} \mathrm{~K} \mathrm{~K}_{2} \mathrm{O}\right)$. The number of branches per plant was maximum in $50 \%$ higher recommended dose of $\mathrm{N}$ and $\mathrm{P}+50 \mathrm{~kg}$

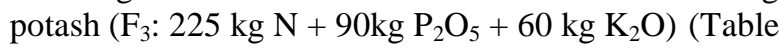
$1)$. This may be explained that partitioning of the nitrogen and phosphorus in to different components of the plant resulted into higher demand of nutrients and established a source and sink relationship. Application of higher doses of $\mathrm{P}$ increased the number of branches. The results are in conformity with Prasad and Naik (2013) conducted an experiment having different treatments resulted in significant effect on number of branches per plant. The maximum number of branches (3.97) was obtained by the application of biofertilizer $($ Azotobacter + Azospirillium + PSB $)+$ FYM (15 t/ha $)+$ RDF (50\%) NPK/ha followed by (3.47) respectively with application of RDF + FYM (15t/ha) and bio-fertilizer (Azotobacter) + FYM (15t/ha). Among the different treat- 
Table 1. Effect of spacing, fertilizer and varieties on plant height at 45, 60, 75 days after sowing and at final harvest and number of branches of okra.

\begin{tabular}{|c|c|c|c|c|c|}
\hline \multirow{2}{*}{$\begin{array}{l}\text { Treatments } \\
\text { Spacing }\end{array}$} & \multicolumn{5}{|c|}{ Plant height (cm) } \\
\hline & 45 DAS & 60 DAS & 75 DAS & $\begin{array}{l}\text { At final } \\
\text { harvest }\end{array}$ & $\begin{array}{c}\text { No. of } \\
\text { branches }\end{array}$ \\
\hline $\mathrm{S}_{1}: 30 \mathrm{~cm} \times 5 \mathrm{~cm}$ & 37.45 & 69.60 & 110.94 & 134.50 & 1.84 \\
\hline $\mathrm{S}_{2}: 30 \mathrm{~cm} \mathrm{x} 10 \mathrm{~cm}$ & 36.50 & 68.51 & 109.50 & 133.63 & 2.20 \\
\hline $\mathrm{S}_{3}: 30 \mathrm{~cm} \mathrm{x} 15 \mathrm{~cm}$ & 30.70 & 63.73 & 105.38 & 129.30 & 2.31 \\
\hline $\mathrm{SEm} \pm$ & 0.51 & 0.29 & 0.51 & 0.38 & 0.02 \\
\hline $\mathrm{CD}$ at $5 \%$ & 2.00 & 1.11 & 2.00 & 1.50 & 0.07 \\
\hline \multicolumn{6}{|c|}{ Fertilizer } \\
\hline $\mathrm{F}_{1}: 150 \mathrm{~kg} \mathrm{~N}+60 \mathrm{~kg} \mathrm{P}_{2} \mathrm{O}_{5}(\mathrm{RD})$ & 32.09 & 64.73 & 106.78 & 130.30 & 1.86 \\
\hline $\mathrm{F}_{2}: 187.5 \mathrm{~kg} \mathrm{~N}+75 \mathrm{~kg} \mathrm{P}_{2} \mathrm{O}_{5}+60 \mathrm{~kg} \mathrm{~K}_{2} \mathrm{O}$ & 37.16 & 69.55 & 110.35 & 134.35 & 2.24 \\
\hline $\mathrm{F}_{3}: 225 \mathrm{~kg} \mathrm{~N}+90 \mathrm{~kg} \mathrm{P}_{2} \mathrm{O}_{5}+60 \mathrm{~kg} \mathrm{~K}_{2} \mathrm{O}$ & 35.41 & 67.56 & 108.67 & 132.31 & 2.26 \\
\hline $\mathrm{SEm} \pm$ & 0.74 & 0.32 & 0.52 & 0.39 & 0.06 \\
\hline $\mathrm{CD}$ at $5 \%$ & 2.23 & 0.99 & 1.61 & 1.20 & 0.18 \\
\hline \multicolumn{6}{|c|}{ Varieties } \\
\hline $\mathrm{V}_{1}$ : Hisar Unnat & 33.13 & 65.31 & 105.41 & 128.81 & 2.16 \\
\hline $\mathrm{V}_{2}:$ HBT-49-1 & 36.64 & 69.25 & 111.79 & 136.52 & 2.07 \\
\hline $\mathrm{SEm} \pm$ & 0.93 & 0.33 & 0.76 & 0.43 & 0.03 \\
\hline $\mathrm{CD}$ at $5 \%$ & 2.77 & 0.99 & 2.27 & 1.28 & 0.08 \\
\hline
\end{tabular}

Table 2. Effect of spacing, fertilizer levels and varieties on yield attributes and yield of okra.

\begin{tabular}{|c|c|c|c|c|c|c|c|}
\hline Treatments & $\begin{array}{c}\text { First } \\
\text { fruiting } \\
\text { node }\end{array}$ & $\begin{array}{l}\text { Internodal } \\
\text { length }(\mathrm{cm})\end{array}$ & $\begin{array}{l}\text { Fruit } \\
\text { length } \\
\text { (cm) }\end{array}$ & $\begin{array}{c}\text { Fruit } \\
\text { diameter } \\
(\mathbf{c m})\end{array}$ & $\begin{array}{c}\text { Fruit } \\
\text { weight } \\
\text { (g) }\end{array}$ & $\begin{array}{c}\text { No. of } \\
\text { fruits per } \\
\text { plant }\end{array}$ & $\begin{array}{l}\text { Fruit } \\
\text { yield } \\
\text { (q/ha) }\end{array}$ \\
\hline \multicolumn{8}{|c|}{ Spacing } \\
\hline $\mathrm{S}_{1}: 30 \mathrm{~cm} \times 5 \mathrm{~cm}$ & 6.15 & 5.15 & 8.61 & 1.40 & 7.31 & 29.69 & 124.20 \\
\hline $\mathrm{S}_{2}: 30 \mathrm{~cm} \times 10 \mathrm{~cm}$ & 5.42 & 4.81 & 8.72 & 1.44 & 7.73 & 35.27 & 126.51 \\
\hline $\mathrm{S}_{3}: 30 \mathrm{~cm} \times 15 \mathrm{~cm}$ & 5.61 & 4.65 & 8.64 & 1.45 & 7.96 & 31.20 & 114.79 \\
\hline $\mathrm{SEm} \pm$ & 0.09 & 0.10 & 0.13 & 0.01 & 0.06 & 1.01 & 0.113 \\
\hline $\mathrm{CD}$ at $5 \%$ & 0.36 & 0.37 & NS & 0.04 & 0.22 & 3.94 & 0.441 \\
\hline \multicolumn{8}{|c|}{ Fertilizer } \\
\hline $\mathrm{F}_{1}: 150 \mathrm{~kg} \mathrm{~N}+60 \mathrm{~kg} \mathrm{P}_{2} \mathrm{O}_{5}$ & 5.33 & 4.18 & 8.34 & 1.39 & 7.46 & 31.07 & 113.55 \\
\hline $\begin{array}{l}\mathrm{F}_{2}: 187.5 \mathrm{~kg} \mathrm{~N}+75 \mathrm{~kg} \\
\mathrm{P}_{2} \mathrm{O}_{5}+60 \mathrm{~kg} \mathrm{~K}_{2} \mathrm{O}\end{array}$ & 5.40 & 5.17 & 9.01 & 1.46 & 7.86 & 33.30 & 126.70 \\
\hline $\begin{array}{l}\mathrm{F}_{3}: 225 \mathrm{~kg} \mathrm{~N}+90 \mathrm{~kg} \mathrm{P}_{2} \mathrm{O}_{5} \\
+60 \mathrm{~kg} \mathrm{~K}_{2} \mathrm{O}\end{array}$ & 6.46 & 5.26 & 8.63 & 1.44 & 7.68 & 31.79 & 125.25 \\
\hline $\mathrm{SEm} \pm$ & 0.08 & 0.08 & 0.11 & 0.02 & 0.10 & 0.47 & 0.287 \\
\hline $\mathrm{CD}$ at $5 \%$ & 0.25 & 0.24 & 0.33 & 0.06 & 0.31 & 1.46 & 0.884 \\
\hline \multicolumn{8}{|c|}{ Varieties } \\
\hline$\overline{\mathrm{V}_{1} \text { : Hisar Unnat }}$ & 5.36 & 5.05 & 8.43 & 1.41 & 7.33 & 30.50 & 118.63 \\
\hline $\mathrm{V}_{2}:$ HBT-49-1 & 6.11 & 4.70 & 8.89 & 1.45 & 8.00 & 33.61 & 125.03 \\
\hline SEm \pm & 0.05 & 0.05 & 0.07 & 0.01 & 0.06 & 0.36 & 0.236 \\
\hline $\mathrm{CD}$ at $5 \%$ & 0.14 & 0.15 & 0.21 & 0.02 & 0.19 & 1.08 & 0.702 \\
\hline
\end{tabular}

ments, biofertilizer (PSB) + FYM (15t/ha) produced minimum number of branches (2.89/plant).

Effect of varieties: It was observed that plant height at different intervals (45, 60, 75 DAS and at final harvest) was significantly higher in variety HBT-49-1 but another character i.e. number of branches per plant were significantly higher in variety Hisar Unnat (2.16) as compared to 2.07 in HBT-49-1. The reason for higher plant height in HBT-49-1 is its genetic constitution which contributed in the higher plant height. The number of branches per plant was also at trait which is higher in case of Hisar Unnat (a selection of Sel 2-2 x Parbhani Kranthi) (Table 1). Likewise, days to 50 per cent flowering with plant height at genotypic level; plant height with number of branches per plant,
This indicates the inter dependency of the various characters on each other. Jayapandi and Balkrishnan (1992) and Chitra (1999) reported similar results.

\section{Studies on yield attributes and yield of okra}

Effect of spacing: Data pertaining to seven yield attributes i.e., first fruiting node, intermodal length, fruit length, diameter and weight, number of fruits per plant and fruit yield were presented in Spacing $30 \times 10 \mathrm{~cm}$ significantly affected the yield attributes like first fruiting node and number of fruits per plant. First fruiting nod was significantly earlier in $30 \times 10 \mathrm{~cm}$ spacing but significant reduction in intermodal length was observed in spacing $30 \times 15 \mathrm{~cm}$. Fruit length was not affected by any spacing. Fruit diameter $(1.45 \mathrm{~cm})$ and fruit weight $(7.96 \mathrm{~g})$ were significantly higher in spac- 
ing $30 \times 15 \mathrm{~cm}$ over $30 \times 5 \mathrm{~cm}$ but on par with $30 \times 10$ $\mathrm{cm}$. Significantly higher number of fruits and fruit yield $(126.51 \mathrm{q} / \mathrm{ha}$ ) were observed in spacing $30 \times 10$ $\mathrm{cm}$ over all the spacing (Table 2). Narrow spacing will result in higher plant population, higher competition for all the resource factors but in wider spacing, this competition will be less which imparts healthier plant s and timely availability of all factors meant for higher yield (Saha et al., 2005). The yield is a factor of plant population. Higher the plant population per unit area, higher will be yield in terms quintal per hectare. This explains the higher yield in spacing $30 \mathrm{~cm} \times 10 \mathrm{~cm}$ as compared to $30 \mathrm{~cm} \times 15 \mathrm{~cm}$. (Gorachand et al., (1990) where maximum okra yield was obtained from closer intra-row spacing of $25 \mathrm{~cm}$. The conflicting results might also be due to the variation in the environment and differences in the genetic potential of the varieties used.

Effect of fertilizer levels: Recommended dose of nitrogen and phosphorus fertilizer resulted in earliness in first fruiting node. It also resulted in largest fruit diameter over all other fertilizer levels. But inter-nodal length of okra was significantly reduced $(4.18 \mathrm{~cm})$ by recommended dose of nitrogen and phosphorus as compared to 25 and $50 \%$ higher recommended dose of nitrogen and phosphorus. In contrast, application of $25 \%$ higher recommended dose of nitrogen and phosphorus plus $50 \mathrm{~kg}$ potash resulted in maximum fruit length, fruit weight, number of fruits per plant and higher fruit yield $126.70 \mathrm{q} / \mathrm{ha}$. Higher fertilizer levels of nitrogen and phosphorus resulted in higher growth and development of the growth parameters which in turn provide more photosynthetic area for the accumulation and translocation of photosynthesis to the sink i.e. fruit (Table 2). Similar results were also reported by Pandey et al., (1976). The maximum weight per fruit $(8.82 \mathrm{~g})$ were recorded $85 \mathrm{~kg} \mathrm{~N} /$ ha followed by 60 $\mathrm{kg} \mathrm{N} / \mathrm{ha}(7.32 \mathrm{~g})$ and $35 \mathrm{~kg} \mathrm{~N} / \mathrm{ha}$ (5.92) respectively. Wider spacing $60 \times 30 \mathrm{~cm}$ recorded maximum weight per fruit $(7.46 \mathrm{~g})$ and superior to $45 \times 30 \mathrm{~cm}(7.41 \mathrm{~g})$ and $30 \times 30 \mathrm{~cm}(7.13 \mathrm{~g})$ respectively. The quoted results are of present study not of Banger et al.

Effect of varieties : Earliness in first fruit node was seen in Hisar Unnat (5.36) as compared to HBT-49-1 (6.11). The intermodal length was higher in Hisar Unnat $(5.05 \mathrm{~cm})$ followed by $4.70 \mathrm{~cm}$ in HBT-49-1. Fruit length was higher in HBT-49-1 $(8.89 \mathrm{~cm})$ than $8.43 \mathrm{~cm}$ in Hisar Unnat variety of okra. Fruit diameter is higher in HBT-49-1 $(1.45 \mathrm{~cm})$ than Hisar Unnat $(1.41 \mathrm{~cm})$. Higher fruit weight $(8.00 \mathrm{~g})$, number of fruits per plant (33.61) and fruit yield (125.03 q/ha) was recorded in HBT-49-1 which are significantly higher than Hisar Unnat. Higher number of yield attributes resulted in higher yield in terms of quintals per hectare in HBT-49-1. The per cent increase in yield over Hisar Unnat is 5.39 in HBT-49-1. Fruit length showed highly significant and positive correlation with number of fruits per plant and internodal length (Table 2). Similar results were also reported by Sood et al. (1993).

\section{Conclusion}

Spacing $30 \mathrm{~cm} \times 10 \mathrm{~cm}$ resulted in higher growth parameters and yield attributes with the application of

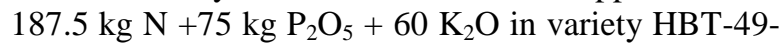
1 of okra. Growth parameters of okra crop were significantly affected by spacing, fertilizer and varieties. Highest plants were observed in wider spacing with fertil-

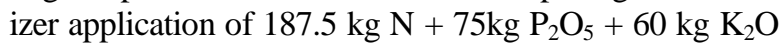
per hectare in variety HBT-49-1. However, numbers of branches were highest in variety Hisar Unnat. Yield attributes like first fruiting node, intermodal length, fruit length and diameter etc. were highest in variety HBT-491 resulting in highest fruit yield $(\mathrm{q} / \mathrm{ha})$ in spacing $30 \mathrm{~cm} \times$ $10 \mathrm{~cm}$ with the application of $187.5 \mathrm{~kg} \mathrm{~N}+75 \mathrm{~kg} \mathrm{P}_{2} \mathrm{O}_{5}+$ $60 \mathrm{~kg} \mathrm{~K} 2 \mathrm{O}$ per hectare. The seed yield attributes and yield was significantly affected by spacing, fertilizer and varieties. Finally, spacing $30 \mathrm{~cm} \times 10 \mathrm{~cm}$ resulted in higher growth parameters, yield attributes and yield with the application of $187.5 \mathrm{~kg} \mathrm{~N}+75 \mathrm{~kg} \mathrm{P}_{2} \mathrm{O}_{5}+60 \mathrm{~K}_{2} \mathrm{O}$ in variety HBT-49-1 of okra.

\section{ACKNOWLEDGMENTS}

The authors are grateful to the Department of Vegetable Science, CCS Haryana Agricultural University, Hisar for providing necessary facilities to carried out the experiment.

\section{REFERENCES}

Anonymous. (2011). Data base of vegetable crops 2010-11. National Horticulture Board, Govt. of India, Gurgaon, Haryana.

Banger, K.S., Parmar, B.B. and Miani, A. (2000). Effect of nitrogen and presumed cake application on yield and uptake of NPK on Sugarcane. Crop Research. 19(2): 198-203.

Chaurasia, S.N.S., De, Nirmal. and Singh, K.P. (2001). Response of nutrient on the performance of okra cv. VOR6. Annual Report. IIVR, Varanasi.

Chitra, K.R., (1999). Variability and correlation studies in okra (Abelmoschus esculentus). M.Sc. (Agri) thesis, Dr. Punjabrao Deshmikh Krishi Vidyapeeth, Akola.

Ekwu, L.G. and Nwokwu, G.N. (2012). Effect of plant spacing and planting date on the growth and yield of okra. International Journal of Agriculture and Rural Development, 15(2): 1041 -1048.

Gorachand, M., Malik, O. and Mondal, G. (1990). Growth and yield of bhindi (Abelmoschus esculentus L. Moench) as influenced by time of sowing and plant density, Orissa Journal of Horticulture. 18: 26-31.

Hossain, M.D., Rahman, M.A., Hoque, M.M. and Salem, M.A. (2001). Year round okra production and economic return as influenced by spacing in Barisal region. Bangladesh Journal of Agricultural Researchearch, 25: 319-328.

Ijoyah, M.O., Unah, P.O. and Fanen, F.T. (2010). Response of okra (Abelmoschus esculentus L. Moench) to intralow spacing in Makurdi, Nigeria. Agricultureculture and Bioogical. Agriculture Journal of N. America. 1(6): 1328-1332, 
Jayapandi, A. and Balkrishanan, R. 1992. Genetic variablity in okra. Indian Journal Horticulture. 49(2): 107-109.

Kumar, T., Kumar, M., Singh, M.K., Kumar, V., Kumar, A., Kumar, S. and Singh, B. (2013). Impact of integrated nutrient management (INM) on growth and economic yield of okra. Annals of Horticulture. 6(1): 107-114.

Kushwaha, V.S. (1989). Effect of different levels of nitrogen and planting density on production of seed potato (Solanum tuberosum L.) as influenced by fertilizer application. Journal of Maharashtra Agriculture University 3(1): 60-61.

Makinde, S.C.O. and Macarthy, A.P. (2006). Effects of intraspecific competition on some agronomic attributes of Celosia argentea (L.) in a field trial. Biological and Environmental Science Journal for the Tropics. 3(3): $115-121$.

Maurya, R.P. (2013). Impact of plant spacing and picking interval on the growth, fruit quality and yield of okra (Abelmoschus esculentus (L.) Moench). American. Journal Agriculture \& Forestry. 1(4): 48-54.

Misra, R.K. and Singh, G. (2005). Effect of sources of nutrients on performance of Okra (Abelmoschus esculentus L. Moench). Sri Lanka Journal Agriculture Sciences. 42: 57-57.

Nath, P., Valayudhan, D. and Singh, D.P. (1987). Vegetable for tropical region. ICAR Book Series No. 3: ICAR, New Delhi, Pp. 91-97.

Pandey, U.C., Pandit, M.L. and Singh, K. (1976). Effect of Spacings and Green fruit pickings in okra. Vegetable Science (2): 97-102.

Prasad, P.H. and Naik, A., (2013). Effect of varying NPK levels and bio-fertilizers on growth and yield of okra [Abelmoschus esculentus (L.) Moench] under sustainable condition. Trends in Biosciences, 6(2): 167-169.

Randhawa, G.S. and Pannum, M.S. (2000). The effects of row spacing on the growth and yield of okra. Punjab Agriculturecultural University Research Journal. 6: 320-324.

Sood, S., Arya, P.S. and Sharma, S.K. 1993. Correlation and path analysis in bhendi (Abelmoschus esculentus (L.) Moench.). Him. Journal Agriculture. Research. 19: 37-42

Talukder, M.A.H., Munnaf, M.A., Alam, M.K., Salam, M.A. and Amin, M.M.U. (2003). Influence of sowing time, plant spacing and picking interval on the growth and the yield of okra. Pakistan Journal of Biological. Sciences. 6(18): 1626-1630.

Vanitha, S.M., Chaurasia, S.N.S. and Singh P.M. (2013). Vegetable Statistics, IIVR, Varanasi, U.P. Technical Bulletin, 51. pp. Vegetable Statistics (2013). pp: 1 